\title{
RESPONSE
}

\section{Response to Priest, Ngolo and Stabell}

\author{
Michael Allen Rynkiewich
}

This article by Priest, Ngolo and Stabell (2020) presents a significant piece of research in an area, child witchcraft accusations, only recently addressed by scholars in the church and in academia. For anthropologists and missionaries alike, witchcraft accusations and practices were a troublesome topic in the period before World War II, but the context there was traditional culture versus Christianity and modernity. As children of the Enlightenment, missionaries denounced occult practices without conceding the presence of spiritual power and anthropologists strove to rationalize witchcraft as a product of uncertainty (Malinowski) and/or a rational response given the assumptions of the ideological system (Evans-Pritchard).

That witchcraft, or at least accusations, should surge rather than politely fade away in postcolonial times confounds the wisdom of secular society raised on the principles of modernity. That women are disproportionately accused worldwide attracts attention in the Western gender-sensitive world, and "witch camps" such as those in northern Ghana confirm the concern. Older women who married in from outside the village or suburb who are now widowed and without the protection of sons and brothers are particularly vulnerable targets.

This is still a common story in Papua New Guinea (PNG) where, as in the Congo, though it is against national law, in rural areas widows are commonly accused, beaten, and even killed as a result of witchcraft accusations. The resurgence of accusations prompts several questions for the church. What kind of witchcraft? What is the occasion for accusations? Who is the accuser and who is the accused? What has the church failed to do? What can the church do now?

What are we dealing with? In both the Congo and PNG, we are not dealing with unadulterated traditional beliefs and practices. Traditional customs varied significantly. The question was the same: Who is the cause of this malady? But in PNG the answer ranged from ghosts of the recent dead, to ghosts of the long dead, to spirits of the bush, each in possible partnership with a willing or an unsuspecting subject. In PNG, for the most part, traditional beliefs and practices declined under pressure from missionaries and administrators. The provision of widespread healthcare and law enforcement in PNG up to the time of independence (1975) as well as the nearly complete conversion to Christianity (96\% of the population make the claim) contributed to the decline.

Independence opened up new routes for the circulation of people and ideas. Even in prehistorical times, there is evidence of the spread of successive waves of new cults in PNG, and now people share their beliefs through traditional routes of transmission as well as through new routes centered around mines and towns. A hybrid complex of beliefs called Sanguma in tok pisin now dominates the field. Some traditional beliefs included paths of redemption and reconciliation. Schram notes for the Auhelawa, for example, that "the evidence for witchcraft belief has traditionally been drawn from confessions given in meetings held among kin to diagnose and cure illness" (2010, 727), but that today both the setting (not kin) and the goal (not curing) have become more dangerous with newly circulated Sanguma beliefs. Sanguma tends to lead to violence (Bartle 2005, 43; Gibbs 2015, 310, 321). Thus perceived witchcraft and the accusations are layered phenomena operating in a mixed social field with declining traditional leadership as well as inadequate legal resources (Gibbs 2012, 133).

It seems clear both in the Congo and Papua New Guinea etiology that, when disaster strikes, there must be a personal spiritual cause; it is not just happenstance. The way to stop a series of unfortunate events is to find the person who is causing the problem. Once found, the person must be exposed, punished and/or eliminated. Finally, the most likely people to be accused are the marginal, weak, and expendable. Marginal in that they will have little support in the community. Weak so that they are unable to defend themselves or retaliate. Expendable in that they are not critically important to anyone in the community.

In the Congo, the problem with the re-emergence of witchcraft accusations is that it targets children and that some local churches and pastors join in rather than resist the movement. In PNG, the church is not actively part of the problem and children are rarely accused. However, the failure of the churches to address witchcraft accusations, and the unfortunate compatibility of some of the newer churches' theology of 
sickness and death with witchcraft beliefs, are certainly contributing factors.

The Catholic Church along with the Lutheran Church have taken the lead in re-thinking and teaching a theology of sickness and death, as well as of good and evil in the world. The presentation of Jesus as a healer as well as one who casts out demons has been helpful because it is pointed out that Jesus worked with grace and forgiveness leading to reconciliation. Jesus never tortured nor harmed the demon-possessed, nor did he ever blame a living person for the sickness of another. In Scripture, God is the ultimate spiritual power, all others are subordinate. Scripture identifies especially the orphan, the widow, and the alien for special care specifically because of their marginality to the community. Finally, the prophets and Jesus stood up for the weak and marginalized. These teachings go a long way.

The Catholic Church, in particular, has had some success in following a plan of action that responds to sickness, death, and accusations. The prescriptions that the church has adopted combine theological education with quick and measured responses (Gibbs 2015, 311312). First, through teaching the church must "broaden people's understanding of the causes of illness and death." Second, church leaders must make a quick response with "early intervention before or during a funeral." Third, the church must seek "immediate family members taking ownership" to "make peace, talk it over, and talk it out." Fourth, the church must be about "promoting respect for law and order." Finally, the church must engage in "fostering faith to influence attitudes and emotions," and thereby create an alternative worldview. All this takes work, and Gibbs provides extended examples to show what these mean in practice.

Thus, responses to witchcraft accusations in PNG range from the demand for rationality (Zocca 2009, 46) to the multi-level interventions listed above. However, there can be, and should be, more.

Cox and Phillips (2015) follow the practice of critical biocultural medical anthropology, in particular the work of anthropologist and medical doctor Paul Farmer, to expand the context. They argue that there is an inverse relationship between health care and law enforcement on the one hand and the severity and suddenness of sickness and death on the other. Thus, they place the resurgence of witchcraft accusations in a historical context of colonialism and a failed state. Neocolonial states on the periphery that continue to base their economy on resource extraction (mining, forestry) have inevitably fallen into debt to the World Bank, and suffer from the structural adjustment programs of the International Monetary Fund. Structural adjustments begin with cutting funds for medical care and education.
Cox and Phillips argue that:

Sorcery accusations are largely associated with untimely or unanticipated deaths, therefore the contest between these ways of thinking and biomedical understandings of disease and illness is important to examine .. . we argue that the explanatory power of biomedicine in PNG and Solomon Islands is hampered by several factors, not least the poor access to and resourcing of medical services $(2015,37)$.

In the case of PNG, this means that clinics, hospitals, and medical staff that were coming up to world class standards at independence in 1975 have now fallen into disrepair. In Goroka, where I lived for four years, there is a hospital that used to be the pride of the region that has fallen on hard times, and there is a newly built clinic that polished up a Member of Parliament's reputation but has never (at least by 2014) opened due to lack of ongoing funds for medical staff. The point is that the very triggers for witchcraft accusations, illness and death, have been on the rise as health care has declined. It does not help, either, that law enforcement is understaffed and underbudgeted. During my time there, the police would routinely ask for petrol when called out for a disturbance because they could not travel without it.

Church plans, such as in the Congo and in PNG are certainly necessary to combat witchcraft accusations, but that is treating the symptoms. The problem is structural: lack of adequate health care and lack of trained and resourced law enforcement. If doctors failed to get at the root causes of disease, there would be lawsuits. Why would the church not want to start with root causes to reduce witchcraft accusations and violence?

\section{References}

Bartle, Neville. 2005. Death, Witchcraft and the Spirit World in the Highlands of Papua New Guinea. Point No. 29. Goroka, PNG: The Melanesian Institute.

Cox, John and Georgina Phillips. 2015. Sorcery, Christianity and the Decline of Medical Services. In Talking it Through: Responses to Sorcery and Witchcraft Beliefs and Practices in Melanesia. Miranda Forsyth and Richard Eves, eds. Pp. 37-54. Canberra, AU: Australia National University Press. https://www.jstor.org/stable/j.ctt169wd7b.6 Accessed December 6, 2019.

Gibbs, Philip. 2012. Engendered Violence and Witch-killing in Simbu. In Engendering Violence in Papua New Guinea. Margaret Jolly, Christine Stewart, and Carolyn 
Brewer, eds. Pp. 107-135. Canberra, AU: Australia National University Press.

https://www.jstor.org/stable/j.ctt24hcwt.10

Accessed December 5, 2019.

Gibbs, Philip. 2015. Practical Church Interventions on Sorcery and Witchcraft Violence in the Papua New Guinea Highlands. In Talking it Through: Responses to Sorcery and Witchcraft Beliefs and Practices in Melanesia. Miranda Forsyth and Richard Eves, eds. Pp. 309-327. Canberra, AU: Australia National University Press.

https://www.jstor.org/stable/j.ctt169wd7b.21

Accessed December 6, 2019.

Haley, Nicole. 2010. Witchcraft, Torture and HIV. In Civic Insecurity: Law, Order and HIV in Papua New Guinea, Volume 6. Vicki Luker and Sinclair Dinnen, eds. Pp. 219-236. Canberra, AU: Australia National University Press.

www.jstor.org/stable/j.ctt24h9kk.20

Accessed December 4, 2019.

Priest, Robert J., Abel Ngolo and Timothy Stabell. 2020. Christian Pastors and Alleged Child Witches in Kinshasa, DRC. On Knowing Humanity Journal 4(1):1-51.

Reithofer, Hans. 2011. Sorcery, Witchcraft, and Christianity in Papua New Guinea: A Review Essay. Anthropos 106(1):196-200.

https://www.jstor.org/stable/23031814

Accessed December 6, 2019.

Schram, Ryan. 2010. Witches' wealth: witchcraft, confession, and Christianity in Auhelawa, Papua New Guinea. The Journal of the Royal Anthropological Institute. 16(4):726742.

https://www.jstor.org/stable/40926177

Accessed December 11, 2019.

Zocca, Franco. 2009. Witchcraft and Christianity in Simbu Province. In Sanguma in Paradise: Sorcery, Witchcraft and Christianity in Papua New Guinea, Point 33. Franco Zocca, ed. Pp. 10-54. Goroka, PNG: The Melanesian Institute.

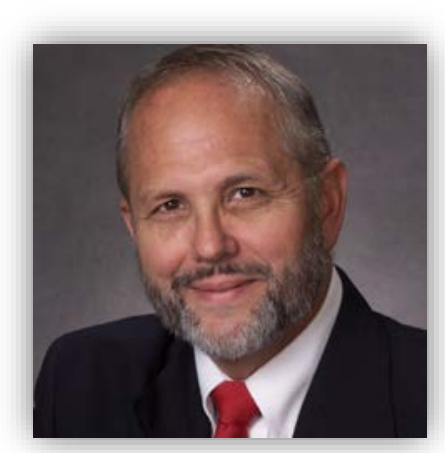

Michael A. Rynkiewich is Professor of Anthropology, retired, from Asbury Seminary. He took his Ph.D. in anthropology from the University of Minnesota (1972) after 18 months fieldwork in the Marshall Islands. He taught for 10 years at Macalester College, and has published a number of books and articles. Later in life he served as a Methodist missionary anthropologist at the Melanesian Institute in Goroka, Eastern Highlands Province, Papua New Guinea. Besides preaching and teaching, he led a four year research project that resulted in two books on problems with church ownership of land. At Asbury Seminary he served as Director of Postgraduate Studies before retiring in 2010 .

\section{Author email:}

Michael.rynkiewich@asburyseminary.edu 